Respirilion

\title{
The Lung in Hereditary Hemorrhagic Telangiectasia
}

\author{
Sophie Dupuis-Girod ${ }^{a, b}$ Vincent Cottin ${ }^{c, d}$ C.L. Shovlin ${ }^{e}$ \\ aService de génétique - centre de référence national pour la maladie de Rendu-Osler, Hôpital Femme-Mère-

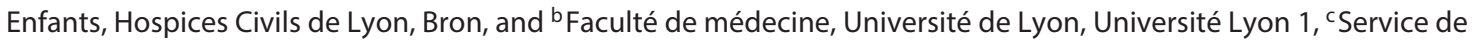 \\ pneumologie - centre de référence national des maladies pulmonaires rares, Hôpital Louis Pradel, Hospices Civils \\ de Lyon, and dUniversité de Lyon, Université Lyon 1, INRA, UMR754, Lyon, France; eNHLI Cardiovascular Sciences, \\ Imperial Centre for Translational and Experimental Medicine, Imperial College London, London, UK
}

\section{Keywords}

Hereditary hemorrhagic telangiectasia · Pulmonary arteriovenous malformations · Pulmonary hypertension . Anemia $\cdot$ Rare vascular disease

\section{Abstract}

Hereditary hemorrhagic telangiectasia (HHT) is a dominantly inherited genetic vascular disorder with an estimated prevalence of 1 in 6,000, characterized by recurrent epistaxis, cutaneous telangiectasia, and arteriovenous malformations (AVMs) that affect many organs including the lungs, gastrointestinal tract, liver, and brain. Its diagnosis is based on the Curaçao criteria, and is considered definite if at least 3 of the 4 following criteria are fulfilled: (1) spontaneous and recurrent epistaxis, (2) telangiectasia, (3) a family history, and (4) pulmonary, liver, cerebral, spinal, or gastrointestinal AVMs. The focus of this review is on delineating how HHT affects the lung.

() 2017 S. Karger AG, Basel

Previous articles in this series: 1. Lazor R, Nicod LP: The lung in rare systemic diseases. Respiration 2017;94:1. 2. Tran C, Barbey F, Lazor $\mathrm{R}$, Bonafé L: Pulmonary involvement in adult patients with inborn errors of metabolism. Respiration 2017;94:2-13. 3. Borie R, Wislez M, Antoine M, Cadranel J: Lymphoproliferative disorders of the lung. Respiration 2017;94:157-175.
}

\section{KARGER}

(C) 2017 S. Karger AG, Basel

E-Mail karger@karger.com

www.karger.com/res

\section{Introduction}

Hereditary hemorrhagic telangiectasia (HHT; Online Mendelian Inheritance in Man ${ }^{\circledR} \# 187300$ ) is a dominantly inherited genetic vascular disorder with an estimated prevalence of 1 in 6,000, characterized by recurrent epistaxis, cutaneous telangiectasia, and arteriovenous malformations (AVMs) that affect many organs including the lungs, gastrointestinal tract, liver, and brain. Diagnosis is based on the Curaçao criteria, and is considered definite if at least 3 of the 4 following criteria are fulfilled [1]: (1) spontaneous and recurrent epistaxis, (2) telangiectasia, (3) a family history, and (4) pulmonary, liver, cerebral, spinal, or gastrointestinal AVMs (Table 1).

HHT is caused by a single pathogenic variant ("mutation"), usually in either ENG (encoding endoglin) [2] or ACVRL1 (encoding activin receptor-like kinase 1, or ALK1) [3]. A smaller proportion of HHT cases $(<5 \%)$ is caused by SMAD4 (also called MADH4, encoding SMAD4) [4] and unidentified mutations, likely in the promoter or intronic regions of these genes, or other genes affecting the same signaling pathway. The endoglin, ALK1, and SMAD4 proteins are components of the transforming growth factor- $\beta /$ bone morphogenetic protein signaling pathways: ALK1 is a type I transmembrane serine threonine receptor kinase, endoglin is an auxiliary

Sophie Dupuis-Girod, MD, PhD

Service de génétique et centre de référence national pour la maladie de Rendu-Osler Hôpital Femme-Mère-Enfants

FR-69677 Bron (France)

E-Mail sophie.dupuis-girod@chu-lyon.fr 
Table 1. Manifestations of HHT and complications

\begin{tabular}{|c|c|c|c|}
\hline Manifestation/lesion & Prevalence & Diagnosis & Complication \\
\hline $\begin{array}{l}\text { Epistaxis/telangiectasia of the } \\
\text { nasal mucosa }\end{array}$ & $>90 \%$ & $\begin{array}{l}\text { Epistaxis beginning in } \\
\text { childhood, often at the } \\
\text { beginning of HHT }\end{array}$ & $\begin{array}{l}\text { Anemia } \\
\text { Acute hemorrhage }\end{array}$ \\
\hline $\begin{array}{l}\text { Mucocutaneous telangiectasia } \\
\text { (lips, oral cavity, tongue, and } \\
\text { fingertips) }\end{array}$ & $80 \%$ & Evident & Cosmetic hemorrhage \\
\hline $\begin{array}{l}\text { Telangiectasia of the } \\
\text { gastrointestinal tract }\end{array}$ & $15-30 \%$ & Endoscopy (upper/lower) & $\begin{array}{l}\text { Anemia } \\
\text { Gastrointestinal hemorrhage }\end{array}$ \\
\hline Pulmonary AVMs & $50 \%$ & $\begin{array}{l}\text { CT scan } \\
\text { Transthoracic contrast } \\
\text { echocardiography }\end{array}$ & $\begin{array}{l}\text { Most often asymptomatic } \\
\text { Right-to-left shunt: stroke, brain abscess, hypoxemia } \\
\text { +/-dyspnea; migraine } \\
\text { Hemorrhage: hemoptysis, hemothorax }\end{array}$ \\
\hline Hepatic vascular malformations & $30-70 \%$ & $\begin{array}{l}\text { Doppler US } \\
\text { CT scan }\end{array}$ & $\begin{array}{l}\text { Most often asymptomatic } \\
\text { Hepatic AVMs: high cardiac output } \pm \text { failure, } \\
\text { postcapillary pulmonary hypertension } \\
\text { Hepatoportal VMs: portal hypertension } \\
\text { Portovenous VMs: biliary ischemia }\end{array}$ \\
\hline Cerebral AVMs & $10-20 \%$ & $\begin{array}{l}\text { MRI } \\
\text { Angiography }\end{array}$ & $\begin{array}{l}\text { Most often asymptomatic } \\
\text { Hemorrhage depends on type } \\
\text { Headache } \\
\text { Epilepsy }\end{array}$ \\
\hline Spinal AVMs & $<1 \%$ & Spinal MRI & $\begin{array}{l}\text { Hemorrhage } \\
\text { Paraplegia (acute, subacute, or progressive) }\end{array}$ \\
\hline
\end{tabular}

HHT, hereditary hemorrhagic telangiectasia; AVMs, arteriovenous malformations.

receptor, and SMAD4 is the common partner for canonical (SMAD-based) signaling [5]. While the exact pathogenic mechanisms are yet to be determined, vascular abnormalities in HHT are thought to arise due to resultant imbalances in the response to angiogenic factors such as vascular endothelial growth factor [6], defective vascular repair [7], and/or modified vessel maturation [8]. Recently, heterozygous missense substitutions in the GDF2 gene, which encodes bone morphogenetic protein 9 , have been reported in individuals with some cutaneous vascular lesions similar to those seen in HHT $[9,10]$, although the pathogenicity of the gene variants remains uncertain. Vascular lesions similar to those present in HHT (such as skin telangiectasia and certain high-flow AVMs) may also be found in other hereditary vasculopathies due to RASA1 and TIE2, which appear to mediate different signaling pathways $[11,12]$.

Pathogenic ENG, ACVRL1, and SMAD4 sequence variants can generate the full spectrum of vascular lesions in HHT, including pulmonary, cerebral, hepatic, and spinal involvement, though ENG mutations are associated with an increased risk of pulmonary AVMs (PAVMs) and cerebral AVMs ( 3- to 6-fold), whereas ACVRL1 variants more frequently cause hepatic AVMs ( 3- to 6-fold) [13-15]. The vascular abnormalities have been reproduced in animal models by heterozygous inactivation of the ENG or ACVRL1 gene $[16,17]$.

The focus of this review is on delineating how HHT affects the lung. In brief:

- PAVMs affect $~ 50 \%$ of all HHT patients [18]; PAVMs result in an anatomical right-to-left shunt, cause hypoxemia, and place patients at high risk of paradoxical embolic strokes and cerebral abscesses [19], but their importance remains underrecognized [20]

- $~ 20 \%$ of HHT patients with no evidence of PAVMs on thoracic CT scans also display evidence of intrapulmonary right-to-left shunting by contrast echocardiography (CE) [21], and there is limited appreciation that 
Fig. 1. Pulmonary arteriovenous malformation on CT scans.

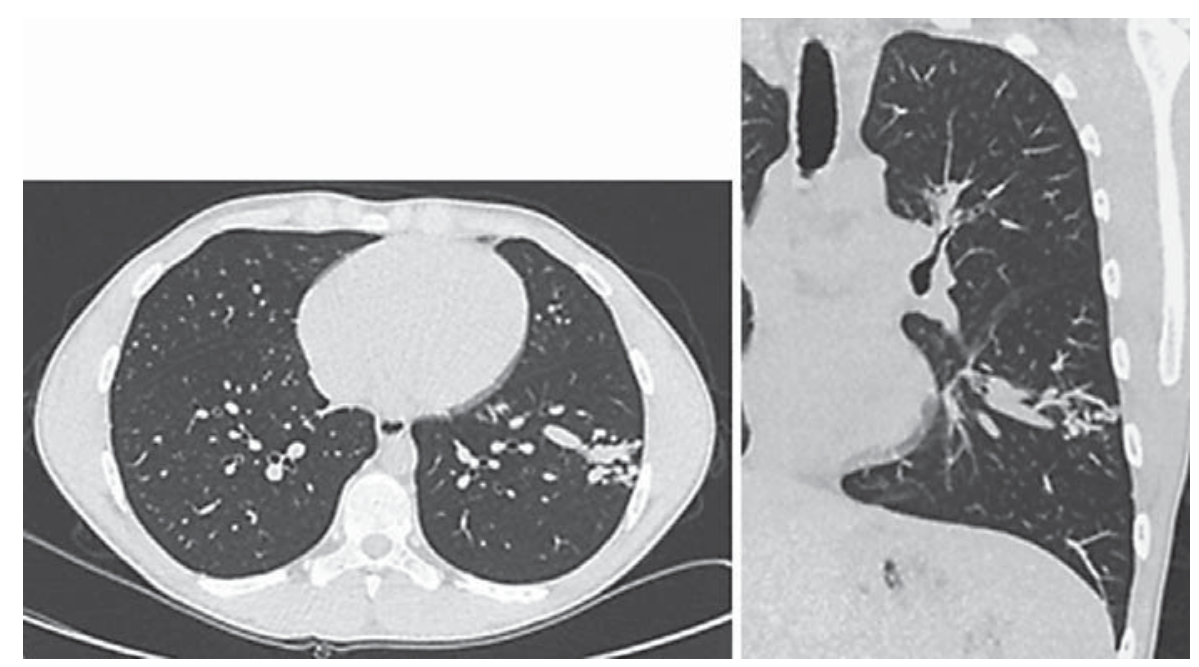

this can be a normal variant in the general population [22]

- Although the focus of many publications, significant pulmonary hypertension $(\mathrm{PH})$ is rare in HHT; supranormal pulmonary artery pressures are identified in up to $20 \%$ of unselected HHT patients [23], but this is usually secondary to a high pulmonary blood flow [24] because of elevated cardiac outputs required to meet the wider circulatory demands imposed by hepatic AVMs and other HHT complications [25]; pulmonary arterial hypertensive phenotypes are rare [26-29]

- There appear to be minor modifications in the incidence of nonvascular pulmonary conditions, particularly lung cancer and sleep apnea

\section{Pulmonary Arteriovenous Malformations}

\section{Definition, Prevalence, and Anatomical}

\section{Considerations}

PAVMs are structurally abnormal vessels (Fig. 1) that provide direct capillary-free communication between the pulmonary and systemic circulations and result in an anatomical right-to-left shunt. They may occur sporadically, but more usually are associated with HHT. The major consequences of PAVMs are impairment of gas exchange (resulting in hypoxemia) and paradoxical emboli (Fig. 2). In less than $2 \%$ of untreated cases, the PAVM may involve a systemic artery rather than a pulmonary artery [30]. PAVMs vascularized by more than one branch of a pulmonary artery or drained by multiple segmental pulmonary veins are labelled "complex PAVMs."

The Lung in Hereditary Hemorrhagic Telangiectasia
PAVMs comprise an aneurismal or serpiginous sac with one or more afferent feeding arteries and one or more efferent draining veins. Based on cross-sectional and angiographic imaging, PAVMs are classified as single (only one macroscopic PAVM) or multiple (several lesions distributed in different lobes or lung segments), noting that each PAVM can itself be complex in structure. The term "diffuse" is used to describe the rare situation of PAVMs, usually small, affecting multiple segmental branches of one lobe or all branches of one segment [31], raising specific challenges to treatment. The severity of right-to-left shunting is defined as the proportion of cardiac output passing through the PAVMs, and may be massive $(>40 \%)$ in patients with large single PAVMs, as well as in patients with more diffuse, smaller PAVMs.

In HHT patients, PAVMs predominate in the lower lobes (60-95\%) and are multiple in at least half of all HHT cases [30] (Fig. 2). In published series, PAVMs do not appear to directly influence spirometric values $[32,33]$.

The prevalence of PAVMs differs according to HHT genotype, being higher in HHT1 due to ENG (up to 58\%) than in HHT2 due to ACVRL1 $(18 \%)(p<0.001)$ [18-21]. PAVMs may be present from birth and have usually completed development by adult life, although they can enlarge later in life - for example, during pregnancy or following other alterations in pulmonary hemodynamics.

\section{Clinical Manifestations and Complications}

Most patients with PAVMs that place them at risk of preventable strokes and brain abscesses are unaware that they have a problem within their lungs. PAVMs continue

Respiration 2017;94:315-330 317 


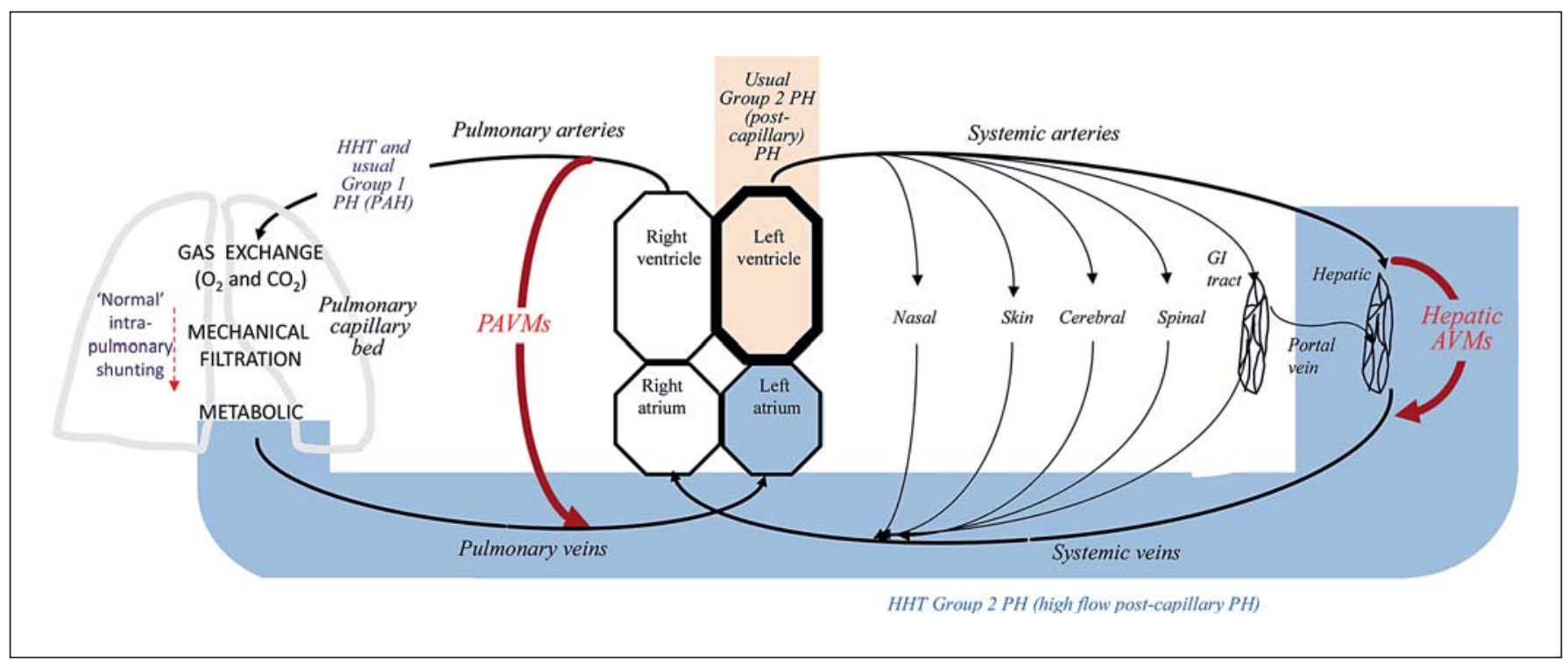

Fig. 2. Schematic of systemic and pulmonary circulations indicating vascular beds commonly affected by HHT. Red arrows denote AVMs. The pulmonary circulation indicates PAVMs, and distinguishes sites of PAH and postcapillary (group 2) PH. The hepatic and portal circulations indicate the three anatomical forms of aberrant hepatic vascular communications: (1) hepatic artery to hepatic vein (arteriovenous, associated with high-output states and group $2 \mathrm{PH}$ ); (2) hepatoportal (hepatic artery to portal vein, associated with portal hypertension); and (3) portovenous (portal vein to hepatic vein). HHT, hereditary hemorrhagic telangiectasia; PAVMs, pulmonary arteriovenous malformations; GI, gastrointestinal; $\mathrm{PH}$, pulmonary hypertension; $\mathrm{PAH}$, pulmonary arterial hypertension. to be more commonly diagnosed by incidental imaging, systematic screening, or investigations after neurological complications than due to respiratory symptoms $[18,34$, 35]. As HHT patients should undergo screening for PAVMs, this should be the main circumstance for the detection of PAVMs.

\section{Paradoxical Emboli}

The major risks of PAVM are neurological due to compromised pulmonary capillary bed filtration, and include cerebral abscess, ischemic stroke, transient ischemic attack, and asymptomatic cerebral infarction. Such complications frequently reveal the diagnosis of PAVM(s), and even of HHT itself. Cerebral abscesses commonly occur in asymptomatic individuals without a prior diagnosis of PAVM or HHT $[34,35]$, and leave approximately $50 \%$ of survivors with residual life-changing neurological deficits [35]. Cerebral abscesses are estimated to affect $5-19 \%$ of patients with PAVMs at a median age of 53 years [18, 34-39]. This translates to an increased rate of $155 / 100,000 /$ year among HHT patients, compared to $0.4 / 100,000 /$ year among the general population [39]. Cerebral abscesses are frequently due to multiple organisms, may follow dental or other interventional procedures, and occur in immunocompetent patients at a median age of 33 years [18].

Crucially, the cerebral abscess data dispel previously proposed myths about the importance of respiratory symptoms, hypoxemia, or feeding artery diameters in establishing which PAVMs require treatment: not only do cerebral abscesses commonly occur in patients with no respiratory symptoms and normal $\mathrm{SaO}_{2}$, but also, across two separate series, in $14 / 65(21.5 \%)$ of the cases, all PAVM feeding arteries had a diameter of $1-3 \mathrm{~mm}$, i.e., at or below the limit of what is commonly considered treatable $[34,35]$. That said, in multivariate analyses of a recent series of 445 consecutive patients with PAVMs, cerebral abscesses were more common in patients with lower $\mathrm{SaO}_{2}$, with the risk of cerebral abscess increasing by $10.47 \%$ (95\% CI: 4.18-16.36) for every $1 \%$ fall in $\mathrm{SaO}_{2}$ [35]. Thus, overall, the risk of cerebral abscess is increased whatever the size of the PAVM or the feeding artery in individuals with more severe right-to-left shunting. In multivariate analyses, cerebral abscess was also associated with indices of iron loading (higher transferrin iron saturation index or intravenous iron use for anemia), male gender, and venous thromboemboli [35]. Other severe infections may occur as a result of PAVMs [38], including 
abscesses in other organs, the spinal cord, or soft tissues, as well as meningitis, septicemia, endocarditis, and bacterial spondylodiscitis.

PAVMs are also strongly associated with an enhanced risk of cerebral ischemia and infarction, again attributable to paradoxical emboli. The rate of a clinical ischemic stroke (duration $>24 \mathrm{~h}$ ) has been reported to lie between 9 and $18 \%$ [18, 34, 40-42] - at $11.3 \%$ when adjusting for ascertainment bias [34] - at a median age of 53 years, and is reduced after embolization of PAVMs [34]. Transient cerebral ischemic attacks affect $6-37 \%$ of PAVM patients [18, 43]. The burden of asymptomatic cerebral infarction is greater still: in one series, 34/67 (51\%) of the patients with PAVMs had CT evidence of cerebral infarcts at a median age of 41 years [44], and in a more recent series of MRIs performed for cerebral AVM screening at a median age of 43 years, "incidental" cerebral ischemic changes were reported in 15/21 (68.2\%) of the HHT patients with PAVMs (PAVM age-adjusted odds ratio 61.1 [95\% CI: 4.3, 874, $p=$ $0.002]$ ) [45]. Ischemic strokes commonly occur in previously asymptomatic individuals without a prior diagnosis of PAVM or HHT $[34,40]$. Recent studies have highlighted that for a patient with a PAVM, the strongest stroke risk factors are low levels of serum iron [40] (which is associated with exuberant platelet aggregation to 5-hydroxytryptamine $[40,46])$ and high levels of serum fibrinogen [40], which is the predominant circulating plasma protein for platelet adhesion [47]. These emphasize the importance of antiplatelet therapies as utilized in conventional ischemic stroke management. Anticoagulants are only recommended if there is separate evidence of deep venous thrombosis or pulmonary emboli, which are rare in PAVM-ischemic stroke patients $[40,48]$.

\section{Respiratory Manifestations}

The most striking clinical finding in this patient group is the presence of asymptomatic hypoxemia [49]: significantly hypoxemic patients with $\mathrm{SaO}_{2}<85 \%$ are often able to pursue sporting activities to a very high level [50], emphasizing the powerful hematological $[49,51]$ and hemodynamic $[52,53]$ compensatory responses that can be employed. Crucially, these compensatory responses are then lost after treatment of PAVMs, and exercise capacity/oxygen delivery usually returns to pretreatment levels $[49,51,53]$. There is no clear relationship between the severity of right-to-left shunting and dyspnea; instead dyspnea appears to be more common in patients with airflow obstruction related to another condition, higher pulmonary artery pressures, anemia, or other indices of ill health $[49,52]$.

The Lung in Hereditary Hemorrhagic Telangiectasia
Cyanosis and clubbing may be present in hypoxemic patients with PAVMs, but cyanosis is masked by anemia, and clubbing severity does not seem to be predictable unless right-to-left shunting is severe. Patients with PAVMs occasionally exhibit orthodeoxia [54], attributable to the basal predominance of PAVMs, but this is usually asymptomatic; platypnea (dyspnea on assuming the upright position) is very rare [54].

Other respiratory symptoms due to untreated PAVMs include hemoptysis and hemothorax resulting from intrabronchial or intrapleural rupture of PAVMs, respectively [55]. These are rare, reflecting the low pressures of the pulmonary circulation, but they are more common (1) in pregnancy (see below) $[56,57],(2)$ if PAVMs acquire a systemic arterial feeder after PAVM embolization [58], or (3) in the setting of $\mathrm{PH}[31,59,60]$. Emergency PAVM treatment by embolization or surgery is effective.

Chest pain is rarely attributable to untreated PAVMs. The apparent association between chest pain and PAVMs in the literature most likely reflects incidental occurrences that precipitated diagnostic imaging.

The presence of PAVMs is also associated with a significant increase in the prevalence of migraine. The risk is approximately doubled if HHT patients have PAVMs, and the migraines often improve after PAVM treatment $[36,61-64]$. Similarly, the prevalence of PAVM is higher in patients with migraines among the HHT population (50 vs. 36\%) [64]. Recent data suggest that the pathophysiological mechanisms may again include paradoxical embolism of particulate matter [65].

Pregnancy and PAVMs

During pregnancy, the risk of PAVM hemorrhage and of maternal death are each on the order of $1 \%$ (among 484 pregnancies, $1.0 \%$ [95\% CI: 0.1-1.9] resulting in a major PAVM bleed and $1.0 \%$ [0.13-1.9] resulting in maternal death) [56]. Both hemoptysis and hemothorax are described $[56,57]$. To reduce maternal and fetal complications related to PAVMs during pregnancy, systematic screening and treatment of PAVMs are recommended prior to pregnancy. PAVMs often increase in size and number during pregnancy, likely due to the increased blood volume and cardiac output. In pregnancy, there are also enhanced risks of pulmonary emboli and of myocardial infarction with normal coronary arteries [56]. Pregnant HHT patients with PAVMs should be offered close follow-up throughout pregnancy: the arterial oxygen content $\left(\mathrm{CaO}_{2}\right)$ appears to be a more relevant and helpful index than $\mathrm{SaO}_{2}$, which may be misleadingly high [51]. If necessary, transcatheter embolotherapy of maternal pul-

Respiration 2017;94:315-330 319 
monary AVMs can be performed [66], although in our practice this is restricted to women who are experiencing hemoptysis.

\section{Diagnosis of PAVM}

Thoracic CT scans using helical multidetectors are the gold standard for the diagnosis of PAVMs, with the ability to detect anatomical PAVMs far below the technical limitations of treatment. Expertise is wide-spread, though diagnostic confusion can result: distinguishing features of possible "PAVM mimics" such as a pulmonary varix, bronchoceles, or pulmonary malinosculations are presented elsewhere [67]. It is important that CT use is restricted: in a single-center study of 246 patients with PAVMs (mean age: 53 years), the mean cumulative effective dose over an 11-year period was $51.7 \mathrm{mSv}$; CT scans repeated according to recommended protocols [68] accounted for $46 \%$ of the cumulative effective dose, compared with 51\% from interventional procedures [69]. Due to potential radiation exposure, recent consensus statements emphasize that CT scans should not be repeated unless there is a new clinical indication [48]. CT should be performed without contrast injection for screening, with injection only if required for confirmation of the diagnosis or pretreatment. Similarly, pulmonary angiography should not be performed as a diagnostic test, and, in experienced centers, is usually only performed at the time of embolization after PAVMs have been anatomically defined by a thoracic CT scan.

\section{Screening for PAVMs in the HHT Population}

Either a negative contrast echocardiogram performed by experienced hands or a negative thoracic CT scan (with or without contrast) excludes clinically significant PAVMs. Transthoracic CE (TTCE) has been recommended as the initial screening test for PAVMs [68] due to its high sensitivity [70] and low risk [71]. TTCE relies on the normal $100 \%$ first-pass clearance of a microbubble on its passage through the alveolar capillaries as the gas diffuses rapidly out of the microbubble into the alveolus down the concentration gradient. TTCE is performed by injecting 4-5 $\mathrm{mL}$ of agitated modified fluid gelatin or isotonic saline solution with $0.5 \mathrm{~mL}$ room air into a peripheral vein, while simultaneously imaging the atria with $2-\mathrm{D}$ echocardiography. Microbubbles seen in the left heart indicate an intracardiac or intrapulmonary right-to-left shunt. A low-dose chest X-ray is often performed prior to TTCE to detect large PAVMs and obviate the need for microbubble injection in patients with high-flow rightto-left shunting. If negative after assessment by expert hands, no further imaging is required to exclude PAVMs, and the study should not need to be repeated. Although TTCE is the recommended screening method in international guidelines, some HHT centers prefer to perform a single thoracic CT to screen for PAVMs in HHT patients, especially because less experienced sonographers in wider respiratory unit practice may overlook relatively small numbers of bubbles. Even using this approach, echocardiography (not TTCE) may be useful to ensure that pulmonary arterial pressures, cardiac output, and the right heart cavities are normal. The choice between using CT and using TTCE to screen for PAVM may therefore depend on physicians' and patients' preferences, patients' age and gender, and resources.

The key interpretive points for TTCE include:

- TTCE is considered positive for intrapulmonary rightto-left shunting if microbubbles appear in the left atrium after a delay (usually 3-4 cardiac cycles is considered a cutoff) or ramp in intensity (in contrast to intracardiac shunts); the intrapulmonary shunt origin is certain if the bubble density is greater in the left heart than in the right, often requiring 30-60 s of recording [72]

- PAVMs are one cause of intrapulmonary right-to-left shunting; intrapulmonary shunting demonstrable by TTCE is also evident in $\sim 10 \%$ of the general population at rest, and the majority of healthy individuals on exercise, and/or after adrenergic stimuli $[22,73,74]$

- A positive intrapulmonary shunt study is also more likely after injury to the delicate pulmonary capillaries, for example, following a second injection of contrast medium [72]

- TTCE is usually positive in HHT1 patients (85\%) [21], and often positive in HHT2 patients (35\%) [21]; semiquantification of the shunt may help distinguish from physiological shunting and enhance the positive predictive value for a PAVM amenable to treatment [75] or complication risk [76]

- In the absence of PAVMs visible on CT scan, a contrast echocardiogram demonstrating an intrapulmonary shunt does not appear to be associated with an enhanced neurological risk in HHT patients [76]; TTCE is therefore not indicated when the presence of a PAVM has already been established by CT or during follow-up of patients with treated PAVMs; there are also reassuring data for the general population indicating that very few exercise-induced arterialized gas bubbles reach the cerebral vasculature [77], although it is not clear that the same applies to nongaseous paradoxical emboli
Dupuis-Girod/Cottin/Shovlin 


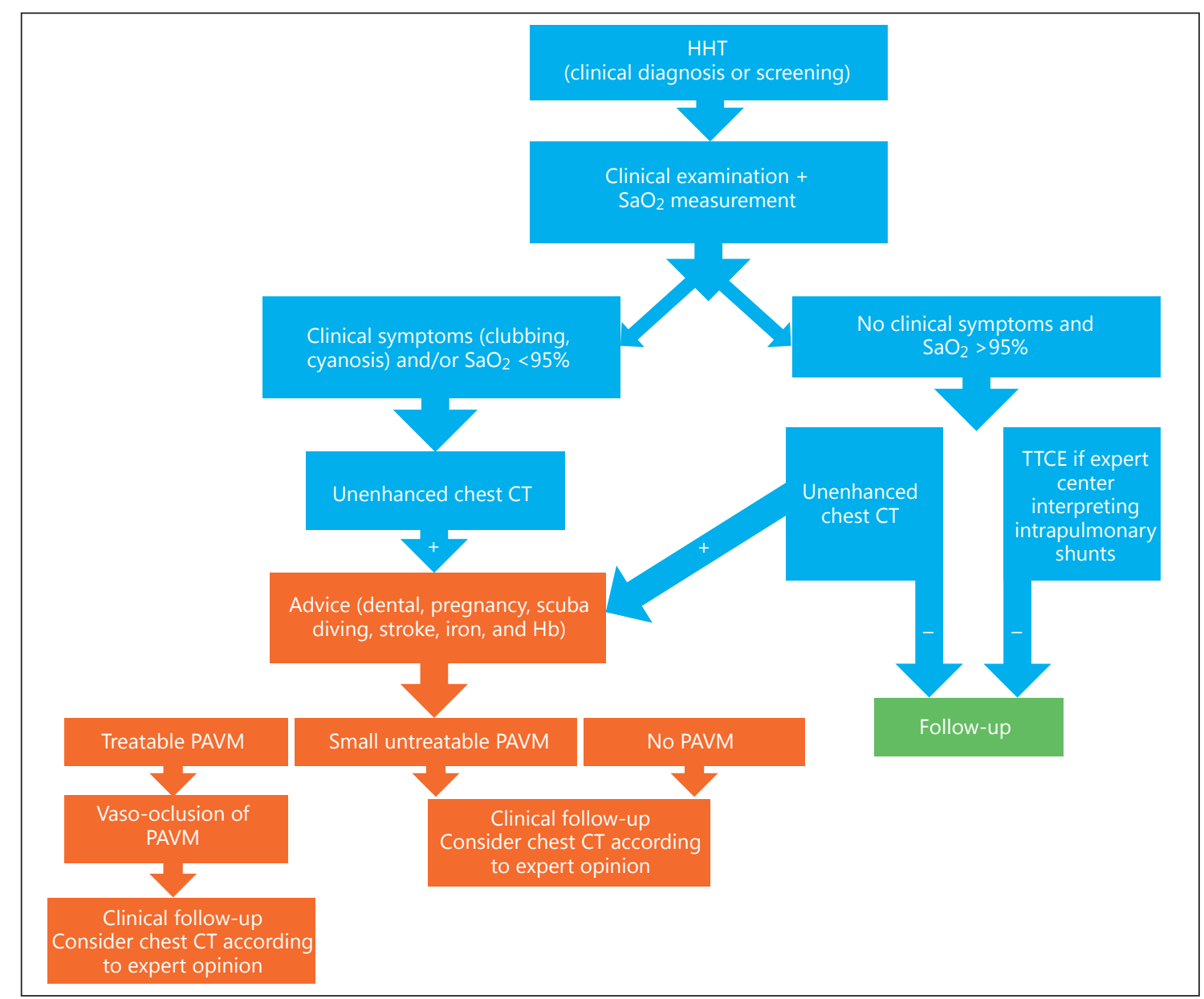

Fig. 3. Algorithms proposed for the screening and follow-up in adult patients with HHT. Radiation-sparing follow-up is recommended, limiting follow-up CT scans to situations when clinically indicated. HHT, hereditary hemorrhagic telangiectasia; PAVM, pulmonary arteriovenous malformation; TTCE, transthoracic contrast echocardiography.

Different algorithms have been proposed for the screening and follow-up of adult patients with HHT according to the degree of local expertise with CE (Fig. 3).

\section{Interventional Treatment of PAVMs}

Treatment of PAVMs in HHT aims at preventing severe complications, especially cerebral abscess, ischemic stroke, and hemorrhage. Interventional treatment is thus warranted in all patients with PAVMs of a size amenable to treatment, irrespective of symptoms $[49,61,78-80]$. PAVM treatment also reduces migraines [61, 81], HHT nosebleeds [82], polycythemia [49,51], and hemodynamic sequelae of PAVMs $[52,53]$. Patients should not undergo embolization expecting improved exercise tolerance, although this may be observed.

The Lung in Hereditary Hemorrhagic Telangiectasia

\section{PAVM Embolization}

Transcatheter vaso-occlusion (embolization) of PAVMs previously used balloons and/or detachable coils with thrombogenic fibers to accelerate platelet thrombus formation [83]. Increasingly, Amplatzer vascular plugs are recommended, as these have greater efficacy and appear to have a lower risk of recanalization [67, 84-86]. Other devices are occasionally used, especially for PAVMs with very large feeding arteries [84]. There is no size threshold (other than technical feasibility) for treatment $[34,35,48,67]$. Multiple PAVMs can be occluded within one procedure, but several procedures can be required to occlude all visible PAVMs, and high proportions of HHT patients are left with residual PAVMs below the technical limits of vaso-occlusion. As for all procedures, it is impor- 
tant that the vaso-occlusion be performed by radiologists experienced in the management and treatment of HHTrelated PAVMs to decrease the risk of complications and improve efficacy: 20 procedures are required for interventional radiologists to meet the VASCERN eligibility requirements [87]. The risks appear to be low in expert hands, and major complications are usually quoted to be on the order of $1 \%$. These include symptomatic lung infarction, systemic migration of embolization devices, air embolism, and, exceptionally, transient angina, cardiac arrhythmia, deep venous thrombosis, or pneumothorax. Infections related to the procedure are minimized by a scrupulous aseptic technique and prophylactic antibiotherapy. More benign complications such as transient pleurisy are reported in approximately $10 \%$ of patients, more frequently in patients with diffuse or peripheral PAVMs [31].

Successful vaso-occlusion of PAVMs immediately decreases right-to-left shunting and improves arterial blood gases; however, residual hypoxemia and positive cardiac $\mathrm{CE}$ results are frequent. Long-term follow-up is mandatory for all HHT patients diagnosed with PAVMs, since they are likely to require ongoing medical management. Once the PAVM sac and dilated draining veins have regressed, PAVMs rarely recur; this can be demonstrated by simple chest X-ray in most cases. In a small proportion of cases, PAVMs may recanalize and acquire new arterial feeders, and vaso-occlusion of large PAVMs may unmask or facilitate the development of new PAVMs [86]. Detection is recommended, as these PAVMs may be successfully treated by repeated vaso-occlusion. The 2006, international guidelines recommended postembolization CT scans at 6-12 months, then every 3 years thereafter, with CT scans every $1-5$ years for other patients with CT-evident PAVMs or positive CE results [68]. These recommendations, however, may be revisited, given the evidence of cumulative radiation burden pursuing this strategy [69], and CT-sparing follow-up strategies may be preferred (Fig. 3) [48].

\section{Surgery}

Surgical treatment of PAVMs, consisting of conservative resection of lung lobes or segments, is currently rare and restricted to complex or multiple PAVMs not amenable to transcatheter therapy. Lung transplantation has occasionally been performed on HHT/PAVM patients $[31,88]$, although PAVMs very rarely cause severe respiratory insufficiency reducing survival expectancy and leading to consideration of lung transplantation, and the life expectancy of patients declining lung transplantation for PAVMs exceeds the most optimistic lung transplantation figures [89].

\section{Medical Management of Patients with PAVMs}

As an adjunct to embolization treatment there are a number of relatively simple lifestyle and medical management recommendations to reduce complication rates from PAVMs [19].

\section{Antibiotic Prophylaxis}

It is often overlooked that in the general population, multiple procedures result in transient bacteremia that is cleared within minutes in the absence of antibiotics, but is prevented or resolved earlier with prior antibiotic administration [90]. Antibiotic prophylaxis immediately prior to dental and surgical procedures has been recommended for many years to patients with PAVMs, and this advice was not changed by the restrictions placed on prophylactic antibiotic use to prevent infective endocarditis [91]. Based on earlier endocarditis guidance, oral administration is conventionally $1-2 \mathrm{~h}$ before a procedure, with a further dose after the procedure. Amoxicillin/clavulanic acid is the preferred agent $[90,91]$, with metronidazole or clindamycin suggested for penicillin-allergic patients [91]. Whether specifically high-risk patients should have intravenous administration is currently under discussion $[35,48,90]$. Also whether prophylactic treatment may be useful for any HHT patient with a positive contrast echocardiogram, including those with no visible PAVM on chest $\mathrm{CT}$, is debated.

Judicious dental hygiene is recommended for patients with PAVMs [91]. Recent data highlight the importance of a scrupulous aseptic technique, prompt treatment of other infections, and prophylactic antibiotics prior to other interventional procedures [35] to attempt to reduce the rate of cerebral abscesses.

\section{Air Emboli}

Scuba diving is not recommended, due to the risk of air embolism [68]. In some countries, the use of air filters is recommended for intravenous infusion to prevent air embolism and transient ischemic attacks; in other countries, expert nursing practice already includes these as "never events," and the risks of modifying protocols may be counterproductive.

\section{Oxygen for Hypoxemic Patients}

Supplementary oxygen can be prescribed to symptomatic patients; there is anecdotal evidence of a benefit, and there may be an additional rationale with recent studies
Dupuis-Girod/Cottin/Shovlin 
Table 2. Pulmonary hemodynamics associated with HHT

\begin{tabular}{llll}
\hline & $\begin{array}{l}\text { Hyperdynamic } \\
\text { circulatory state }\end{array}$ & $\begin{array}{l}\text { Excess fluid } \\
\text { volume }\end{array}$ & PAH \\
\hline $\begin{array}{lll}\text { Mean pulmonary artery pressure } \\
\text { Pulmonary vascular resistance }\end{array}$ & $\uparrow$ & $\uparrow$ & $\uparrow \uparrow$ \\
Cardiac output & $\downarrow$ & $\rightarrow$ & $\uparrow \uparrow$ \\
$\begin{array}{l}\text { Pulmonary artery wedge pressure } \\
\text { Precapillary pressure gradient (diastolic pulmonary }\end{array} \quad$ artery pressure minus pulmonary artery wedge pressure) & $\rightarrow$ & $\uparrow$ & $\rightarrow$ or $\downarrow$ \\
$\quad$
\end{tabular}

HHT, hereditary hemorrhagic telangiectasia; PAH, pulmonary artery hypertension (group 1); $\uparrow$, increased; $\downarrow$, decreased; $\rightarrow$, unchanged.

demonstrating that low $\mathrm{PaO}_{2}$ (not $\mathrm{CaO}_{2}$ ) is the stimulus that mediates the opening of normal intrapulmonary shunts [74]. There is no rationale for prophylactic oxygen use to prevent hypoxic $\mathrm{PH}$, because there is no alveolar hypoxia $[52,54]$.

\section{Iron Deficiency}

Optimization of the iron status is emerging as a core principle for the management of patients with PAVMs, particularly those with HHT and substantial iron loss from nosebleeds [92]. Iron deficiency restricts hemoglobin synthesis/erythrocytosis, and this is an even greater problem for patients with hypoxemia, since they depend on polycythemia to maintain the arterial oxygen content $[49,51]$, and for patients needing to achieve enhanced cardiac outputs due to low systemic vascular resistance (e.g., AVMs, sepsis) and/or hypoxemia [52, 53]. Iron deficiency is also associated with enhanced risks of venous [93] and arterial [40] thromboses in the HHT/PAVM population. However, iron deficiency treatments may inadvertently place patients with prior iron deficiency into at least transient iron overload states $[35,94,95]$, and with recent evidence that this may enhance the risk of cerebral abscesses [35], and other bacterial infections [96], some caution is required.

\section{Pulmonary Hypertension in HHT}

Significant PH is observed in around $8 \%$ of HHT patients, usually secondary to high cardiac output [24], particularly in association with liver vascular malformations [97-100]. This is distinct from the rarer pulmonary arterial hypertension $(\mathrm{PAH})$ phenotype, with different phys-

The Lung in Hereditary Hemorrhagic

Telangiectasia iopathology and treatment algorithms (Table 2; Fig. 3). The key differentiating variable is the pulmonary artery wedge pressure (Table 2). The precapillary pulmonary gradient (diastolic pulmonary artery pressure minus the pulmonary artery wedge pressure as an estimate of left atrial pressure; normal: $<7 \mathrm{~mm} \mathrm{Hg}$ ) may also contribute in difficult cases, especially combined postcapillary and precapillary $\mathrm{PH}$; it is normal in high-output cardiac failure (HOCF)-related $\mathrm{PH}$, but increased in patients with $\mathrm{PAH}$.

\section{Types of $\mathrm{PH}$ in $\mathrm{HHT}$}

AVM Associated, Secondary to High Cardiac Output and High Pulmonary Blood Flow

Where $\mathrm{PH}$ is present in HHT, it is usually secondary to a high pulmonary flow and increased cardiac output (in older classifications referred to as "postcapillary PH"). Although technically falling within the current group 2 $\mathrm{PH}$ umbrella [101], this is not a disorder of the left ventricle, and, again, the diagnostics and therapeutic algorithms should differ.

Systemic AVMs are one of the classic pathologies associated with high-cardiac-output states: reduced systemic vascular resistance leads to a fall in arterial blood pressure, activation of sympathetic and neurohormonal systems, and increased cardiac output to maintain vital organ perfusion at the expense of salt and water retention [102-104]. High left atrial filling pressures lead to pulmonary venous hypertension [102-104], and the increases in cardiac output may exceed the pump capacity of healthy left ventricles, leading to HOCF $[103,104]$.

Such patients usually have an elevated cardiac output, mildly elevated left atrial pressures, and low pulmonary vascular resistance (PVR). The $\mathrm{PH}$ improves following treatment of hepatic AVMs; in one study, after liver trans-

Respiration 2017;94:315-330 
plantation that removed hepatic AVMs, the mean cardiac index fell from 5.75 to $3.4 \mathrm{~L} / \mathrm{min} / \mathrm{m}^{2}$ [105]. However, some hepatic AVM patients show secondary decreases in cardiac output at an advanced stage of heart failure [26], which can be misleading if no previous data on the cardiac index are available.

Other Types of PH That May Occur in HHT Patients More rarely, $\mathrm{PAH}$ is observed (group 1), which is a "true" pulmonary arteriopathy. Patients have elevated pulmonary artery pressures, a normal left atrial pressure, a normal or reduced cardiac output, and significantly increased PVR.

There is a third, rarer group of HHT patients with liver involvement and a chronically high cardiac output, or with portal hypertension, in whom post- and precapillary $\mathrm{PH}$ can be observed. It is not yet known whether chronic exposure to an increased flow leads to remodeling of the pulmonary vascular bed as in Eisenmenger syndrome, but, intriguingly, one such case resolved following liver transplantation (Shovlin, unpublished observation).

Finally, it is also possible for patients with HHT, as for people without HHT, to suffer from thromboembolic $\mathrm{PH}$, hypoxic $\mathrm{PH}$ in the setting of parenchymal lung disease, and other forms of $\mathrm{PH}$; there are no data to indicate whether these pathologies are more or less common in HHT. Importantly, hypoxemia due to pulmonary AVMs does not lead to hypoxic $\mathrm{PH}$, which depends on pulmonary vasoconstriction secondary to alveolar hypoxia, not arterial hypoxemia.

PAH is predominantly recognized in HHT2 patients due to ACVRL1 mutations; whether specific ACVRL1 genotypes influence the development of HHT (potentially with PAVM, or liver AVM and hyperdynamic $\mathrm{PH}$ ) or idiopathic PAH is not yet clear. Other major genes, modifier genes, and/or environmental factors are likely to contribute to its pathogenesis.

\section{Screening and Investigation of $\mathrm{PH}$}

Systematic screening for $\mathrm{PH}$ is not recommended for asymptomatic HHT patients. However, $\mathrm{PH}$ assessments should be incorporated into the diagnostic algorithms for any patient with unexplained shortness of breath or exercise limitation; echocardiography with estimation of the atrioventricular pressure gradient and cardiac index measurement should be systematically performed and liver evaluation and follow-up are mandatory to interpret the cardiac data.

Echocardiography is therefore an important method for patients with HHT, contributing to screening for both
PAVM and right-to-left shunting using the contrast method, and further evaluating possible $\mathrm{PH}$ whatever its mechanism (high cardiac output or high PVR). The presence of dilated right-sided chambers and/or an increased velocity of the tricuspid regurgitation jet should prompt right-heart catheterization, which is required to confirm $\mathrm{PH}$ and to characterize its mechanism.

\section{Mechanism and Management of $\mathrm{PH}$ due to an}

Increased Cardiac Output and Hyperdynamic State in HHT (Group 2 PH)

While in principle any systemic AVM will result in reduced systemic vascular resistance and activation of the renin/angiotensin/aldosterone system [104], in practice in HHT this is usually observed in the setting of large hepatic AVMs $[26,103,106]$.

Liver involvement in HHT is detected in $41-78 \%$ of HHT patients using sensitive imaging technique [100, 107-109], though more commonly in HHT2 patients with pathogenic variants in ACVRL1. The evolution of vascular lesions consists in the progressive enlargement and creation of multiple direct AVMs [110]. The Doppler ultrasound grade evaluates multiple anatomical and dynamic features, and ranges from $0+$ for a hepatic artery diameter of $5-6 \mathrm{~mm}$, a peak flow velocity $<80 \mathrm{~cm} / \mathrm{s}$, and a vascular resistivity index $<0.55$ through grades $1-4$ defined by enlargement and increased flow velocity of the hepatic artery, hepatic artery branches (developing tortuosity), and hepatic veins, together with modifications of portal vein flow [98]. As emphasized by the recent EASL guidelines [111], $8 \%$ of patients with liver VMs will be symptomatic [100, 112, 113], and intense medical treatment successfully treats the majority of these [109, 111].

However, liver VMs in HHT can result in three important complications, including HOCF at a rate of $1.2 \mathrm{per}$ 100 person-years [111] (in addition to portal hypertension and biliary necrosis). In the literature, HOCF symptoms were often observed in the 6th or 7th decade of life, including dyspnea, decreased exercise tolerance and fatigue, palpitations, peripheral edema, and ascites $[26,100$, $112,114,115]$.

Ginon et al. [26] proposed a tentative description of disease course based on cardiac complications (Fig. 4) and the severity of $\mathrm{PH}$, starting with a high-output state preceding left cardiac failure, and eventually further $\mathrm{PH}$ and right cardiac failure. Only few data are available about natural history, follow-up, and prognosis in HHT, and these focus more on the clinical phenotype of HOCF than $\mathrm{PH}$. In the largest prospective series, onset of iron deficiency anemia was the most common precipitator of 
Fig. 4. Relationship between pulmonary hypertension and hepatic venous malformations in hereditary hemorrhagic telangiectasia, adapted from Ginon et al. [26]. Further mechanistic contributions from: A, other causes of reduced systemic vascular resistance (e.g., other arteriovenous malformations, sepsis); $\mathrm{B}$, other mechanisms of reduced arterial oxygen content (e.g., hypoxemia); C, mechanisms including left atrial enlargement, and adrenergic stimuli to meet increased cardiac demands; $\mathrm{D}$, right heart failure developing with severe pulmonary hypertension. Repeated echocardiography with cardiac index measurements and classification with other cardiac parameters is important to follow up patients with liver venous malformations and possible evolution over time.

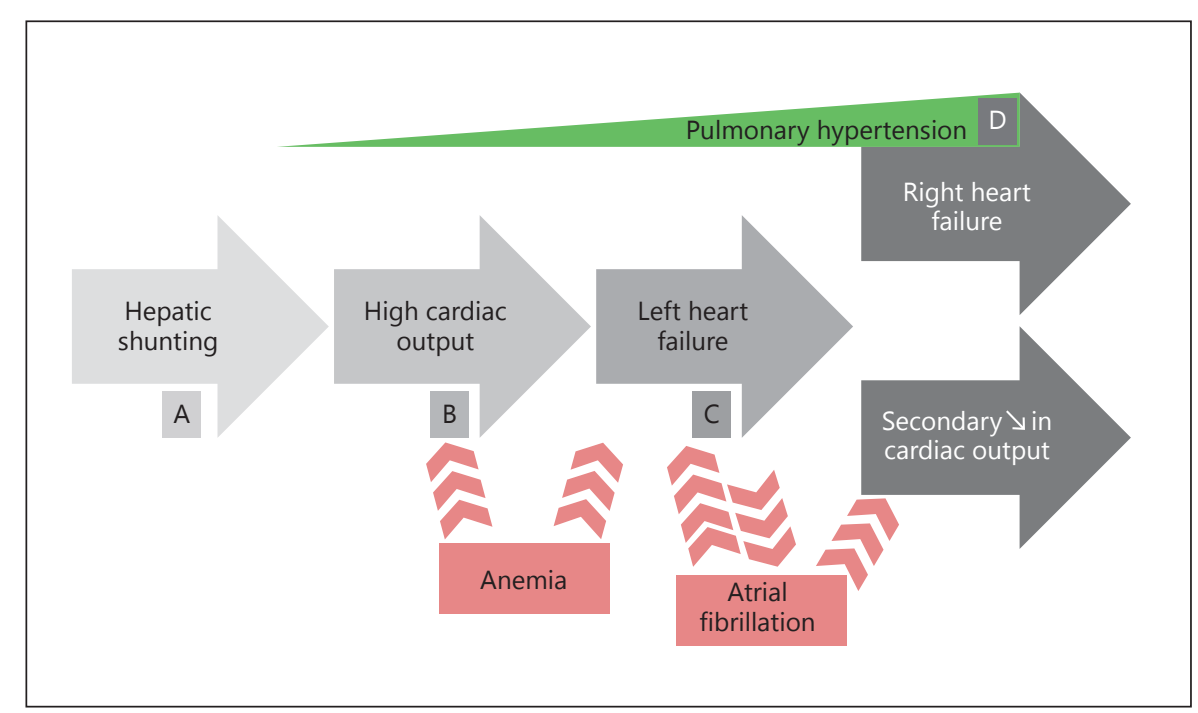

HOCF [112], which was supported by a second series in which HOCF appeared more commonly following a worsening of nosebleeds [114]. Progressive left atrial enlargement and likely an increased adrenergic drive appear to initiate a particularly difficult cycle with the development of atrial fibrillation that reduces the stroke volume.

Importantly for respiratory physicians, treatment of $\mathrm{PH}$ in the setting of hepatic AVMs and high cardiac output will differ substantially from the more usual PAH algorithms: symptomatic treatment includes salt restriction and diuretics, as well as optimal correction of iron deficiency, anemia, and atrial fibrillation, although this is not always efficacious. ACE inhibitors or beta-blockers have been tried, but they were not evaluated in patients with HOCF [104]. The majority of patients treated in this way demonstrate complete or partial resolution of symptoms, but these are not curative [111].

Liver transplantation is the only curative option for liver involvement in HHT $[99,105,116]$, and is associated with complete or partial reversibility of HOCF and $\mathrm{PH}$ [105]. However, the optimal timing for liver transplantation remains unclear, as the morbidity is higher in patients at an advanced stage and in poor medical condition, with concurrent $\mathrm{PH}$ associated with stormier perioperative courses; a PVR $<240$ dyn s cm${ }^{-5}$ has been suggested as a cutoff [99]. Despite the risks, when undertaken, postoperative mortality from orthotopic liver transplantation (OLT) in HHT is modest at $7-10 \%$, and the long-term survival ( $>10$ years) is excellent, ranging from 82 to $92 \%$ [105, 116]. Although hepatic artery ligation, banding, and embolization have been associated with improved cardiac symptoms, the significant associated morbidity and mortality mean that these are no longer recommended $[68,111]$.

Antiangiogenic therapy with an anti-vascular endothelial growth factor antibody (bevacizumab) might be effective in reducing the liver size and may be an interesting option in treating HOCF [117-119]. However, as relapses are observed after the end of treatment, OLT is still now the only radical cure for liver VMs in patients under the age of 65 years. Bevacizumab is recommended, either for patients over the age of 65 years or for those who are poor candidates for surgery; if the latter respond to bevacizumab, they can be reevaluated for OLT (on a "fast track") [120].

\section{Mechanism and Management of $P A H$}

(Group 1 or PAH)

$\mathrm{PAH}$ is caused by remodeling of small pulmonary arteries, with lumen narrowing and subsequent right heart failure and death. PAH in the absence of liver AVMs is very rare in HHT; its prevalence has recently been evaluated in France and estimated to be lower than 5\% of confirmed PH in HHT [Revuz et al., 2017, in review]; however, it has not been systematically evaluated.

PAH in HHT is clinically indistinguishable from idiopathic PAH (with severe, progressive dyspnea on exertion and progressive right heart failure) and histologically similar to idiopathic $\mathrm{PAH}$, with intimal hyperplasia, medial thickening and remodeling, in situ thrombosis, and plexiform lesions [27-29, 121-123]. 


\section{PAVMs and $\mathrm{PH}$ in HHT}

Special considerations are warranted with regard to unusual HHT patients with both PAVMs and PH. Anecdotally, vaso-occlusion of PAVMs in a patient with $\mathrm{PH}$ can lead to a sudden increase in right ventricular afterload and precipitate right heart failure. However, in a large series, the pulmonary arterial pressure was not generally modified by PAVM embolization [80]. Testing the hemodynamic consequences of PAVM vaso-occlusion by transient occlusion of the feeding vessel by an inflatable balloon has been proposed, but this did not predict the outcome in one published case [80]. Thus, as practiced some years ago [124], while vaso-occlusion of PAVMs in patients with known $\mathrm{PH}$ is technically possible, for patients with severe $\mathrm{PH}$, based on current evidence, we would not usually interpret risk-benefit considerations to be in favor of PAVM embolization unless a patient had life-threatening hemoptysis or hemothorax. The risk of a rapid increase in size of PAVMs and of hemorrhage related to PAVM rupture might be heightened in individuals with severe $\mathrm{PH}[60]$.

The natural history and long-term outcomes of HHTassociated PAH are unknown, but they are no better than those of PAH due to BMPR2, with one series suggesting the outcome is worse than for patients with PAH due to ACVRL1 [29]. To what extent patients with HHT and $\mathrm{PAH}$ may benefit from modification of PAH management algorithms remains to be determined.
HHT and Other Lung Pathologies

There currently is no evidence that HHT influences the likelihood of patients developing common respiratory conditions such as asthma, COPD, or interstitial lung disease - although, as noted above, the presence of such conditions may limit an individual's ability to generate the exuberant ventilatory responses required for PAVM compensation [52]. There are tantalizing data that sleep apnea may be 2.6 -fold more common among patients with HHT [125] at a prevalence of 69/100,000, in comparison to $27 / 100,000$ in the general population. Recent data have suggested that HHT may be associated with a reduced incidence of cancer in general [126, 127], and specifically primary or secondary lung cancer [127]. The mechanisms remain speculative.

\section{Conclusions}

HHT is an important condition for the practicing pulmonologist. Where formalized regional or national screening/treatment programs are instituted, the life expectancy is increased when compared to historical controls and similar countries operating less well-implemented screening programs $[127,128]$. The recent approval of the European Reference Network (VASCERN HHT; https://vascern.eu/expertise/rare-diseases-wgs/ hht-wg/) is likely to improve visibility, transborder care, training, educational opportunities, and hopefully research for clinicians seeking greater insight into this important and long-overlooked condition.

\section{References}

1 Shovlin CL, Guttmacher AE, Buscarini E, Faughnan ME, Hyland RH, Westermann CJ, Kjeldsen AD, Plauchu H: Diagnostic criteria for hereditary hemorrhagic telangiectasia (Rendu-Osler-Weber syndrome). Am J Med Genet 2000;91:66-67.

- 2 McAllister KA, Grogg KM, Johnson DW, Gallione CJ, Baldwin MA, Jackson CE, Helmbold EA, Markel DS, McKinnon WC, Murrell $J$, et al: Endoglin, a TGF- $\beta$ binding protein of endothelial cells, is the gene for hereditary haemorrhagic telangiectasia type 1 . Nat Genet 1994;8:345-351.

-3 Johnson DW, Berg JN, Baldwin MA, Gallione CJ, Marondel I, Yoon SJ, Stenzel TT, Speer M, Pericak-Vance MA, Diamond A, Guttmacher AE, Jackson CE, Attisano L, Kucherlapati R, Porteous ME, Marchuk DA: Mutations in the activin receptor-like kinase 1 gene in hereditary haemorrhagic telangiectasia type 2 . Nat Genet 1996;13:189-195.
4 Gallione CJ, Repetto GM, Legius E, Rustgi AK, Schelley SL, Tejpar S, Mitchell G, Drouin E, Westermann CJ, Marchuk DA: A combined syndrome of juvenile polyposis and hereditary haemorrhagic telangiectasia associated with mutations in MADH4 (SMAD4). Lancet 2004;363:852-859.

5 Jakobsson L, van Meeteren LA: Transforming growth factor beta family members in regulation of vascular function: in the light of vascular conditional knockouts. Exp Cell Res 2013; 319:1264-1270.

6 David L, Mallet C, Mazerbourg S, Feige JJ, Bailly S: Identification of BMP9 and BMP10 as functional activators of the orphan activin receptor-like kinase 1 (ALK1) in endothelial cells. Blood 2007;109:1953-1961.
Dingenouts CK, Goumans MJ, Bakker W: Mononuclear cells and vascular repair in HHT. Front Genet 2015;6:114.

8 Thalgott J, Dos-Santos-Luis D, Lebrin F: Pericytes as targets in hereditary hemorrhagic telangiectasia. Front Genet 2015;6:37.

\$ Wooderchak-Donahue WL, McDonald J, O'Fallon B, Upton PD, Li W, Roman BL, Young S, Plant P, Fulop GT, Langa C, Morrell NW, Botella LM, Bernabeu C, Stevenson DA, Runo JR, Bayrak-Toydemir P: BMP9 mutations cause a vascular-anomaly syndrome with phenotypic overlap with hereditary hemorrhagic telangiectasia. Am J Hum Genet 2013;93:530-537.

10 Hernandez F, Huether R, Carter L, Johnston T, Thompson J, Gossage JR, Chao E, Elliott AM: Mutations in RASA1 and GDF2 identified in patients with clinical features of hereditary hemorrhagic telangiectasia. Hum Genome Var 2015;2:15040. 
-11 Revencu N, Boon LM, Mendola A, Cordisco MR, Dubois J, Clapuyt P, Hammer F, Amor $\mathrm{DJ}$, Irvine AD, Baselga E, et al: RASA1 mutations and associated phenotypes in 68 families with capillary malformation-arteriovenous malformation. Hum Mutat 2013;34:16321641.

12 Nguyen HL, Boon LM, Vikkula M: Genetics of vascular malformations. Semin Pediatr Surg 2014;23:221-226.

13 Letteboer TG, Mager JJ, Snijder RJ, Koeleman BP, Lindhout D, Ploos van Amstel JK, Westermann CJ: Genotype-phenotype relationship in hereditary haemorrhagic telangiectasia. J Med Genet 2006;43:371-377.

- 14 Abdalla SA, Geisthoff UW, Bonneau D, Plauchu H, McDonald J, Kennedy S, Faughnan ME, Letarte M: Visceral manifestations in hereditary haemorrhagic telangiectasia type 2 . J Med Genet 2003;40:494-502.

-15 Lesca G, Olivieri C, Burnichon N, Pagella F, Carette MF, Gilbert-Dussardier B, Goizet C, Roume J, Rabilloud M, Saurin JC, Cottin V, Honnorat J, Coulet F, Giraud S, Calender A, Danesino C, Buscarini E, Plauchu H: Genotype-phenotype correlations in hereditary hemorrhagic telangiectasia: data from the French-Italian HHT network. Genet Med 2007;9:14-22.

$\checkmark 16$ Bourdeau A, Cymerman U, Paquet ME, Meschino W, McKinnon WC, Guttmacher AE, Becker L, Letarte M: Endoglin expression is reduced in normal vessels but still detectable in arteriovenous malformations of patients with hereditary hemorrhagic telangiectasia type 1. Am J Pathol 2000;156:911-923.

17 Srinivasan S, Hanes MA, Dickens T, Porteous ME, Oh SP, Hale LP, Marchuk DA: A mouse model for hereditary hemorrhagic telangiectasia (HHT) type 2. Hum Mol Genet 2003;12: 473-482.

18 Cottin V, Chinet T, Lavolé A, Corre R, Marchand E, Reynaud-Gaubert M, Plauchu H, Cordier JF: Pulmonary arteriovenous malformations in hereditary hemorrhagic telangiectasia: a series of 126 patients. Medicine (Baltimore) 2007;86:1-17.

19 Shovlin CL: Pulmonary arteriovenous malformations. Am J Respir Crit Care Med 2014; 190:1217-1228.

-20 Shovlin CL, Gossage JR: Pulmonary arteriovenous malformations: evidence of physician under-education. ERJ Open Res 2017;3: 00104-2016.

-21 van Gent MW, Post MC, Snijder RJ, Westermann CJ, Plokker HW, Mager JJ: Real prevalence of pulmonary right-to-left shunt according to genotype in patients with hereditary hemorrhagic telangiectasia: a transthoracic contrast echocardiography study. Chest 2010;138:833-839.

-22 Laurie SS, Elliott JE, Goodman RD, Lovering AT: Catecholamine-induced opening of intrapulmonary arteriovenous anastomoses in healthy humans at rest. J Appl Physiol (1985) 2012;113:1213-1222.
23 Olivieri C, Lanzarini L, Pagella F, Semino L, Corno S, Valacca C, Plauchu H, Lesca G, Barthelet M, Buscarini E, Danesino C: Echocardiographic screening discloses increased values of pulmonary artery systolic pressure in 9 of 68 unselected patients affected with hereditary hemorrhagic telangiectasia. Genet Med 2006;8:183-190.

24 Vorselaars VM, Velthuis S, Snijder RJ, Vos JA, Mager JJ, Post MC: Pulmonary hypertension in hereditary haemorrhagic telangiectasia. World J Cardiol 2015;7:230-237.

25 Shovlin CL: Circulatory contributors to the phenotype in hereditary hemorrhagic telangiectasia. Front Genet 2015;6:101.

26 Ginon I, Decullier E, Finet G, Cordier JF, Marion D, Saurin JC, Dupuis-Girod S: Hereditary hemorrhagic telangiectasia, liver vascular malformations and cardiac consequences. Eur J Intern Med 2013;24:e35-e39.

27 Trembath RC, Thomson JR, Machado RD, Morgan NV, Atkinson C, Winship I, Simonneau G, Galie N, Loyd JE, Humbert M, Nichols WC, Morrell NW, Berg J, Manes A, McGaughran J, Pauciulo M, Wheeler L: Clinical and molecular genetic features of pulmonary hypertension in patients with hereditary hemorrhagic telangiectasia. N Engl J Med 2001;345:325-334.

28 Harrison RE, Flanagan JA, Sankelo M, Abdalla SA, Rowell J, Machado RD, Elliott CG, Robbins IM, Olschewski H, McLaughlin V, Gruenig E, Kermeen F, Halme M, Räisänen-Sokolowski A, Laitinen T, Morrell NW, Trembath RC: Molecular and functional analysis identifies ALK-1 as the predominant cause of pulmonary hypertension related to hereditary haemorrhagic telangiectasia. J Med Genet 2003;40:865-871.

29 Girerd B, Montani D, Coulet F, Sztrymf B, Yaici A, Jaïs X, Tregouet D, Reis A, DrouinGarraud V, Fraisse A, Sitbon O, O’Callaghan DS, Simonneau G, Soubrier F, Humbert M: Clinical outcomes of pulmonary arterial hypertension in patients carrying an $A C V R L 1$ (ALK1) mutation. Am J Respir Crit Care Med 2010;181:851-861.

30 Cottin V, Dupuis-Girod S, Lesca G, Cordier JF: Pulmonary vascular manifestations of hereditary hemorrhagic telangiectasia (RenduOsler disease). Respiration 2007;74:361-378. 31 Pierucci P, Murphy J, Henderson KJ, Chyun DA, White RI Jr: New definition and natural history of patients with diffuse pulmonary arteriovenous malformations: twenty-sevenyear experience. Chest 2008;133:653-661.

32 Rotenberg C, Bonay M, El Hajjam M, Blivet S, Beauchet A, Lacombe P, Chinet T: Effect of pulmonary arteriovenous malformations on the mechanical properties of the lungs. BMC Pulm Med 2017;17:64.

-33 Gupta P, Mordin C, Curtis J, Hughes JM, Shovlin CL, Jackson JE: Pulmonary arteriovenous malformations: effect of embolization on right-to-left shunt, hypoxemia, and exercise tolerance in 66 patients. AJR Am J Roentgenol 2002;179:347-355.
Shovlin CL, Jackson JE, Bamford KB, Jenkins IH, Benjamin AR, Ramadan H, Kulinskaya E: Primary determinants of ischaemic stroke/ brain abscess risks are independent of severity of pulmonary arteriovenous malformations in hereditary haemorrhagic telangiectasia. Thorax 2008;63:259-266.

35 Boother EJ, Brownlow S, Tighe HC, Bamford KB, Jackson JE, Shovlin CL: Cerebral abscess associated with odontogenic bacteremias, hypoxemia, and iron loading in immunocompetent patients with right-to-left shunting through pulmonary arteriovenous malformations. Clin Infect Dis 2017, Epub ahead of print.

36 Post MC, Letteboer TG, Mager JJ, Plokker TH, Kelder JC, Westermann CJ: A pulmonary right-to-left shunt in patients with hereditary hemorrhagic telangiectasia is associated with an increased prevalence of migraine. Chest 2005;128:2485-2489.

37 Cahill DP, Barker FG 2nd, Davis KR, Kalva SP, Sahai I, Frosch MP: Case records of the Massachusetts General Hospital. Case 102010. A 37-year-old woman with weakness and a mass in the brain. N Engl J Med 2010; 362:1326-1333.

38 Dupuis-Girod S, Giraud S, Decullier E, Lesca G, Cottin V, Faure F, Merrot O, Saurin JC, Cordier JF, Plauchu H: Hemorrhagic hereditary telangiectasia (Rendu-Osler disease) and infectious diseases: an underestimated association. Clin Infect Dis 2007;44:841-845.

39 Kjeldsen AD, Tørring PM, Nissen H, Andersen PE: Cerebral abscesses among Danish patients with hereditary haemorrhagic telangiectasia. Acta Neurol Scand 2014;129:192197.

40 Shovlin CL, Chamali B, Santhirapala V, Livesey JA, Angus G, Manning R, Laffan MA, Meek J, Tighe HC, Jackson JE: Ischaemic strokes in patients with pulmonary arteriovenous malformations and hereditary hemorrhagic telangiectasia: associations with iron deficiency and platelets. PLoS One 2014;9: e88812.

41 Gossage JR, Kanj G: Pulmonary arteriovenous malformations. A state of the art review. Am J Respir Crit Care Med 1998;158:643661.

42 Circo S, Gossage JR: Pulmonary vascular complications of hereditary haemorrhagic telangiectasia. Curr Opin Pulm Med 2014;20: 421-428.

43 Shovlin CL, Letarte M: Hereditary haemorrhagic telangiectasia and pulmonary arteriovenous malformations: issues in clinical management and review of pathogenic mechanisms. Thorax 1999;54:714-729.

44 Moussouttas M, Fayad P, Rosenblatt M, Hashimoto M, Pollak J, Henderson K, Ma TY, White RI: Pulmonary arteriovenous malformations: cerebral ischemia and neurologic manifestations. Neurology 2000;55:959-964. 
45 Fatania G, Patel MC, Jackson JE, Shovlin CL: Burden of cerebral infarcts identified by screening cerebral MRI scans in patients with pulmonary arteriovenous malformations. Thorax 2017, in press.

-46 Woods H, Youdim M, Boullin D, Callender S: Monoamine metabolism and platelet function in iron-deficiency anaemia. Ciba Found Symp 1976;51:227-248.

47 Nieswandt B, Pleines I, Bender M: Platelet adhesion and activation mechanisms in arterial thrombosis and ischaemic stroke. J Thromb Haemost 2011;9(suppl 1):92-104.

48 Shovlin C, Condliffe R, Donaldson J, Kiely D, Wort S: British Thoracic Society clinical statement on pulmonary arteriovenous malformations. London, British Thoracic Society, 2017.

-49 Santhirapala V, Williams LC, Tighe HC, Jackson JE, Shovlin CL: Arterial oxygen content is precisely maintained by graded erythrocytotic responses in settings of high/normal serum iron levels, and predicts exercise capacity: an observational study of hypoxaemic patients with pulmonary arteriovenous malformations. PLoS One 2014;9:e90777.

50 Yasuda W, Jackson JE, Layton DM, Shovlin CL: Hypoxaemia, sport and polycythaemia: a case from Imperial College London. Thorax 2015;70:601-603.

51 Rizvi A, Macedo P, Babawale L, Tighe HC, Hughes JMB, Jackson JE, Shovlin CL: Hemoglobin is a vital determinant of arterial oxygen content in hypoxemic patients with pulmonary arteriovenous malformations. Ann Am Thorac Soc 2017;14:903-911.

-52 Howard LS, Santhirapala V, Murphy K, Mukherjee B, Busbridge M, Tighe HC, Jackson JE, Hughes JM, Shovlin CL: Cardiopulmonary exercise testing demonstrates maintenance of exercise capacity in patients with hypoxemia and pulmonary arteriovenous malformations. Chest 2014;146:709-718.

-53 Vorselaars VM, Velthuis S, Mager JJ, Snijder RJ, Bos WJ, Vos JA, van Strijen MJ, Post MC: Direct haemodynamic effects of pulmonary arteriovenous malformation embolisation. Neth Heart J 2014;22:328-333.

54 Santhirapala V, Chamali B, McKernan H, Tighe HC, Williams LC, Springett JT, Bellenberg HR, Whitaker AJ, Shovlin CL: Orthodeoxia and postural orthostatic tachycardia in patients with pulmonary arteriovenous malformations: a prospective 8 -year series. Tho$\operatorname{rax} 2014 ; 69: 1046-1047$.

55 Faughnan ME, Granton JT, Young LH: The pulmonary vascular complications of hereditary haemorrhagic telangiectasia. Eur Respir J 2009;33:1186-1194.

56 Shovlin CL, Sodhi V, McCarthy A, Lasjaunias P, Jackson JE, Sheppard MN: Estimates of maternal risks of pregnancy for women with hereditary haemorrhagic telangiectasia (OslerWeber-Rendu syndrome): suggested approach for obstetric services. BJOG 2008; 115 : 1108-1115. de Gussem EM, Lausman AY, Beder AJ, Edwards $\mathrm{CP}$, Blanker $\mathrm{MH}$, Terbrugge $\mathrm{KG}, \mathrm{Ma}$ ger JJ, Faughnan ME: Outcomes of pregnancy in women with hereditary hemorrhagic telangiectasia. Obstet Gynecol 2014;123:514-520.

58 Brillet PY, Dumont P, Bouaziz N, Duhamel A, Laurent F, Remy J, Remy-Jardin M: Pulmonary arteriovenous malformation treated with embolotherapy: systemic collateral supply at multidetector CT angiography after 2-20-year follow-up. Radiology 2007;242: 267-276.

-59 Sagara K, Miyazono N, Inoue H, Ueno K, Nishida H, Nakajo M: Recanalization after coil embolotherapy of pulmonary arteriovenous malformations: study of long-term outcome and mechanism for recanalization. AJR Am J Roentgenol 1998;170:727-730.

60 Cottin V, Gamondes D, Schuller A, Coudurier M, Dupuis-Girod S, Tronc F, Cordier JF: Near-fatal haemorrhage from pulmonary arteriovenous malformation in HHT with increased cardiac output. Eur Respir Rev 2009; 18:190-192.

61 Post MC, Thijs V, Schonewille WJ, Budts W, Snijder RJ, Plokker HW, Westermann CJ: Embolization of pulmonary arteriovenous malformations and decrease in prevalence of migraine. Neurology 2006;66:202-205.

62 Post MC, van Gent MW, Plokker HW, Westermann CJ, Kelder JC, Mager JJ, Overtoom TT, Schonewille WJ, Thijs V, Snijder RJ: Pulmonary arteriovenous malformations associated with migraine with aura. Eur Respir J 2009;34:882-887.

63 Elphick A, Shovlin CL: Relationships between epistaxis, migraines, and triggers in hereditary hemorrhagic telangiectasia. Laryngoscope 2014;124:1521-1528.

64 Marziniak M, Jung A, Guralnik V, Evers S, Prudlo J, Geisthoff UW: An association of migraine with hereditary haemorrhagic telangiectasia independently of pulmonary right-toleft shunts. Cephalalgia 2009;29:76-81.

65 Patel T, Elphick A, Jackson JE, Shovlin CL: Injections of intravenous contrast for computerized tomography scans precipitate migraines in hereditary hemorrhagic telangiectasia subjects at risk of paradoxical emboli: implications for right-to-left shunt risks. Headache 2016;56:1659-1663.

66 Gershon AS, Faughnan ME, Chon KS, Pugash RA, Clark JA, Bohan MJ, Henderson KJ, Hyland RH, White RI Jr: Transcatheter embolotherapy of maternal pulmonary arteriovenous malformations during pregnancy. Chest 2001;119:470-477.

-67 Gill SS, Roddie ME, Shovlin CL, Jackson JE: Pulmonary arteriovenous malformations and their mimics. Clin Radiol 2015;70:96-110.

68 Faughnan ME, Palda VA, Garcia-Tsao G, Geisthoff UW, McDonald J, Proctor DD, Spears J, Brown DH, Buscarini E, Chesnutt MS, et al: International guidelines for the diagnosis and management of hereditary haemorrhagic telangiectasia. J Med Genet 2011;48: 73-87.
Hanneman K, Faughnan ME, Prabhudesai V: Cumulative radiation dose in patients with hereditary hemorrhagic telangiectasia and pulmonary arteriovenous malformations. Can Assoc Radiol J 2014;65:135-140.

70 Cottin V, Plauchu H, Bayle JY, Barthelet M, Revel D, Cordier JF: Pulmonary arteriovenous malformations in patients with hereditary hemorrhagic telangiectasia. Am J Respir Crit Care Med 2004;169:994-1000.

71 Nanthakumar K, Graham AT, Robinson TI, Grande P, Pugash RA, Clarke JA, Hutchison SJ, Mandzia JL, Hyland RH, Faughnan ME: Contrast echocardiography for detection of pulmonary arteriovenous malformations. Am Heart J 2001;141:243-246.

72 Shovlin CL, Wilmshurst P, Jackson JE: Pulmonary arteriovenous malformations and other pulmonary aspects of hereditary haemorrhagic telangiectasia. Eur Respir Mon 2011; 54:218-245.

73 Romac R, Barak O, Glavas D, Susilovic Grabovac Z, Lozo P, Roje I, Caljkusic K, Drmic-Hofman I, Davis JT, Dujic Z, Lovering AT: Characterization of blood flow through intrapulmonary arteriovenous anastomoses and patent foramen ovale at rest and during exercise in stroke and transient ischemic attack patients. Echocardiography 2017;34:676682.

74 Duke JW, Davis JT, Ryan BJ, Elliott JE, Beasley KM, Hawn JA, Byrnes WC, Lovering AT: Decreased arterial $\mathrm{PO}_{2}$, not $\mathrm{O}_{2}$ content, increases blood flow through intrapulmonary arteriovenous anastomoses at rest. J Physiol 2016;594:4981-4996.

75 Velthuis S, Buscarini E, Mager JJ, Vorselaars VM, van Gent MW, Gazzaniga P, Manfredi G, Danesino C, Diederik AL, Vos JA, Gandolfi S, Snijder RJ, Westermann CJ, Post MC: Predicting the size of pulmonary arteriovenous malformations on chest computed tomography: a role for transthoracic contrast echocardiography. Eur Respir J 2014;44:150159.

76 Velthuis S, Buscarini E, van Gent MW, Gazzaniga P, Manfredi G, Danesino C, Schonewille WJ, Westermann CJ, Snijder RJ, Mager JJ, Post MC: Grade of pulmonary right-to-left shunt on contrast echocardiography and cerebral complications: a striking association. Chest 2013;144:542-548.

-77 Barak OF, Madden D, Lovering AT, Lambrechts K, Ljubkovic M, Dujic Z: Very few exercise-induced arterialized gas bubbles reach the cerebral vasculature. Med Sci Sports Exerc 2015;47:1798-1805.

78 Hsu CC, Kwan GN, Thompson SA, EvansBarns H, van Driel ML: Embolisation for pulmonary arteriovenous malformation. Cochrane Database Syst Rev 2012;8:CD008017. 
79 Vorselaars VM, Velthuis S, Swaans MJ, Mager JJ, Snijder RJ, Rensing BJ, Boersma LV, Post MC: Percutaneous left atrial appendage closure - an alternative strategy for anticoagulation in atrial fibrillation and hereditary hemorrhagic telangiectasia? Cardiovasc Diagn Ther 2015;5:49-53.

80 Shovlin CL, Tighe HC, Davies RJ, Gibbs JS, Jackson JE: Embolisation of pulmonary arteriovenous malformations: no consistent effect on pulmonary artery pressure. Eur Respir J 2008;32:162-169.

81 Thenganatt J, Schneiderman J, Hyland RH, Edmeads J, Mandzia JL, Faughnan ME: Migraines linked to intrapulmonary right-to-left shunt. Headache 2006;46:439-443.

82 Shovlin CL, Patel T, Jackson JE: Embolisation of PAVMs reported to improve nosebleeds by a subgroup of patients with hereditary haemorrhagic telangiectasia. ERJ Open Res 2016;2: 00035-2016.

83 Ray C, McKinley C, Bauer J: Embolization agents; in Mauro M, Murphy K, Thomson K, Venbrux A, Morgan R (eds): Image-Guided Interventions. Philadelphia, Elsevier Saunders, 2014, pp 41ff.

84 Trerotola SO, Pyeritz RE: PAVM embolization: an update. AJR Am J Roentgenol 2010; 195:837-845.

85 Lacombe P, Lacout A, Marcy PY, Binsse S, Sellier J, Bensalah M, Chinet T, BourgaultVillada I, Blivet S, Roume J, Lesur G, Blondel JH, Fagnou C, Ozanne A, Chagnon S, El Hajjam M: Diagnosis and treatment of pulmonary arteriovenous malformations in hereditary hemorrhagic telangiectasia: an overview. Diagn Interv Imaging 2013;94:835-848.

-86 Woodward CS, Pyeritz RE, Chittams JL, Trerotola SO: Treated pulmonary arteriovenous malformations: patterns of persistence and associated retreatment success. Radiology 2013;269:919-926.

87 VASCERN - The European Reference Network on Rare Multisystemic Vascular Diseases. https://vascern.eu/.

88 Fukushima H, Mitsuhashi T, Oto T, Sano Y, Kusano KF, Goto K, Okazaki M, Date H, Kojima Y, Yamagishi H, Takahashi T: Successful lung transplantation in a case with diffuse pulmonary arteriovenous malformations and hereditary hemorrhagic telangiectasia. Am J Transplant 2013;13:3278-3281.

89 Shovlin C, Buscarini E, Hughes J, Allison D, Jackson J: Long terms outcomes for patients with pulmonary arteriovenous malformations considered for lung transplantation, compared to similarly hypoxemic cohorts. BMJ Open Res 2017, accepted.

90 Limeres Posse J, Álvarez Fernández M, Fernández Feijoo J, Medina Henríquez J, Lockhart PB, Chu VH, Diz Dios P: Intravenous amoxicillin/clavulanate for the prevention of bacteraemia following dental procedures: a randomized clinical trial. J Antimicrob Chemother 2016;71:2022-2030.
-91 Shovlin C, Bamford K, Wray D: Post-NICE 2008: antibiotic prophylaxis prior to dental procedures for patients with pulmonary arteriovenous malformations (PAVMs) and hereditary haemorrhagic telangiectasia. $\mathrm{Br}$ Dent J 2008;205:531-533.

$\$ 92$ Finnamore H, Le Couteur J, Hickson M, Busbridge M, Whelan K, Shovlin CL: Hemorrhage-adjusted iron requirements, hematinics and hepcidin define hereditary hemorrhagic telangiectasia as a model of hemorrhagic iron deficiency. PLoS One 2013;8: e76516.

-93 Livesey JA, Manning RA, Meek JH, Jackson JE, Kulinskaya E, Laffan MA, Shovlin CL: Low serum iron levels are associated with elevated plasma levels of coagulation factor VIII and pulmonary emboli/deep venous thromboses in replicate cohorts of patients with hereditary haemorrhagic telangiectasia. Thorax 2012;67:328-333.

-94 Shovlin CL, Gilson C, Busbridge M, Patel D, Shi C, Dina R, Abdulla FN, Awan I: Can iron treatments aggravate epistaxis in some patients with hereditary hemorrhagic telangiectasia? Laryngoscope 2016;126:2468-2474.

95 Chamali B, Finnamore H, Manning R, Laffan MA, Hickson M, Whelan K, Shovlin CL: Dietary supplement use and nosebleeds in hereditary haemorrhagic telangiectasia - an observational study. Intractable Rare Dis Res 2016;5:109-113.

-96 Bruhn KW, Spellberg B: Transferrin-mediated iron sequestration as a novel therapy for bacterial and fungal infections. Curr Opin Microbiol 2015;27:57-61.

-97 Garcia-Tsao G, Korzenik JR, Young L, Henderson KJ, Jain D, Byrd B, Pollak JS, White RI Jr: Liver disease in patients with hereditary hemorrhagic telangiectasia. N Engl J Med 2000;343:931-936.

-98 Gincul R, Lesca G, Gelas-Dore B, Rollin N, Barthelet M, Dupuis-Girod S, Pilleul F, Giraud S, Plauchu H, Saurin JC: Evaluation of previously nonscreened hereditary hemorrhagic telangiectasia patients shows frequent liver involvement and early cardiac consequences. Hepatology 2008;48:1570-1576.

-99 Buscarini E, Plauchu H, Garcia Tsao G, White RI Jr, Sabbà C, Miller F, Saurin JC, Pelage JP, Lesca G, Marion MJ, Perna A, Faughnan ME: Liver involvement in hereditary hemorrhagic telangiectasia: consensus recommendations. Liver Int 2006;26:10401046.

100 Garcia-Tsao G: Liver involvement in hereditary hemorrhagic telangiectasia (HHT). J Hepatol 2007;46:499-507.

101 Naeije R, D'Alto M: The diagnostic challenge of group 2 pulmonary hypertension. Prog Cardiovasc Dis 2016;59:22-29.

102 Anand IS, Chandrashekhar Y, Ferrari R, Poole-Wilson PA, Harris PC: Pathogenesis of oedema in chronic severe anaemia: studies of body water and sodium, renal function, haemodynamic variables, and plasma hormones. Br Heart J 1993;70:357-362.
103 Ingram CW, Satler LF, Rackley CE: Progressive heart failure secondary to a high output state. Chest 1987;92:1117-1118.

104 Mehta PA, Dubrey SW: High output heart failure. QJM 2009;102:235-241.

105 Dupuis-Girod S, Chesnais AL, Ginon I, Dumortier J, Saurin JC, Finet G, Decullier E, Marion D, Plauchu H, Boillot O: Long-term outcome of patients with hereditary hemorrhagic telangiectasia and severe hepatic involvement after orthotopic liver transplantation: a single-center study. Liver Transpl 2010;16:340-347.

106 Nieminen MS, Böhm M, Cowie MR, Drexler H, Filippatos GS, Jondeau G, Hasin Y, Lopez-Sendon J, Mebazaa A, Metra M, et al: Executive summary of the guidelines on the diagnosis and treatment of acute heart failure: the Task Force on Acute Heart Failure of the European Society of Cardiology. Eur Heart J 2005;26:384-416.

107 Ianora AA, Memeo M, Sabba C, Cirulli A, Rotondo A, Angelelli G: Hereditary hemorrhagic telangiectasia: multi-detector row helical CT assessment of hepatic involvement. Radiology 2004;230:250-259.

108 Brenard R, Chapaux X, Deltenre P, Henrion J, De Maeght S, Horsmans Y, Borbath I, Leenaerts A, Van Cauter J, Francque S, Sersté T, Moreno C, Orlent H, Mengeot P, Lerut J, Sempoux C: Large spectrum of liver vascular lesions including high prevalence of focal nodular hyperplasia in patients with hereditary haemorrhagic telangiectasia: the Belgian Registry based on 30 patients. Eur J Gastroenterol Hepatol 2010;22:1253-1259.

109 Buscarini E, Danesino C, Olivieri C, Lupinacci G, De Grazia F, Reduzzi L, Blotta P, Gazzaniga P, Pagella F, Grosso M, Pongiglione G, Buscarini L, Plauchu H, Zambelli A: Doppler ultrasonographic grading of hepatic vascular malformations in hereditary hemorrhagic telangiectasia - results of extensive screening. Ultraschall Med 2004;25: 348-355.

110 Buscarini E, Danesino C, Olivieri C, Lupinacci G, Zambelli A: Liver involvement in hereditary haemorrhagic telangiectasia or Rendu-Osler-Weber disease. Dig Liver Dis 2005;37:635-645.

111 EASL Clinical Practice Guidelines: vascular diseases of the liver. J Hepatol 2016;64:179202.

112 Buscarini E, Leandro G, Conte D, Danesino C, Daina E, Manfredi G, Lupinacci G, Brambilla G, Menozzi F, De Grazia F, Gazzaniga P, Inama G, Bonardi R, Blotta P, Forner P, Olivieri C, Perna A, Grosso M, Pongiglione G, Boccardi E, Pagella F, Rossi G, Zambelli A: Natural history and outcome of hepatic vascular malformations in a large cohort of patients with hereditary hemorrhagic teleangiectasia. Dig Dis Sci 2011;56:21662178 . 
113 Singh S, Swanson KL, Hathcock MA, Kremers WK, Pallanch JF, Krowka MJ, Kamath PS: Identifying the presence of clinically significant hepatic involvement in hereditary haemorrhagic telangiectasia using a simple clinical scoring index. J Hepatol 2014;61: 124-131.

-114 Khalid SK, Pershbacher J, Makan M, Barzilai B, Goodenberger D: Worsening of nose bleeding heralds high cardiac output state in hereditary hemorrhagic telangiectasia. Am J Med 2009;122:779.e1-e9.

115 Faughnan ME, Palda VA, Garcia-Tsao G, Geisthoff UW, McDonald J, Proctor DD, Spears J, Brown DH, Buscarini E, Chesnutt MS, et al: International guidelines for the diagnosis and management of hereditary haemorrhagic telangiectasia. J Med Genet 2011;48:73-87.

116 Lerut J, Orlando G, Adam R, Sabbà C, Pfitzmann R, Klempnauer J, Belghiti J, Pirenne J, Thevenot T, Hillert C, Brown CM, Gonze D, Karam V, Boillot O: Liver transplantation for hereditary hemorrhagic telangiectasia: report of the European liver transplant registry. Ann Surg 2006;244:854-862; discussion 862-864.

117 Mitchell A, Adams LA, MacQuillan G, Tibballs J, vanden Driesen R, Delriviere L: Bevacizumab reverses need for liver transplantation in hereditary hemorrhagic telangiectasia. Liver Transpl 2008;14:210-213.
18 Flieger D, Hainke S, Fischbach W: Dramatic improvement in hereditary hemorrhagic telangiectasia after treatment with the vascular endothelial growth factor (VEGF) antagonist bevacizumab. Ann Hematol 2006;85: 631-632.

119 Dupuis-Girod S, Ginon I, Saurin JC, Marion D, Guillot E, Decullier E, Roux A, Carette MF, Gilbert-Dussardier B, Hatron PY, Lacombe $\mathrm{P}$, Lorcerie $\mathrm{B}$, Rivière $\mathrm{S}$, Corre $\mathrm{R}$, Giraud S, Bailly S, Paintaud G, Ternant D, Valette PJ, Plauchu H, Faure F: Bevacizumab in patients with hereditary hemorrhagic telangiectasia and severe hepatic vascular malformations and high cardiac output. JAMA 2012;307:948-955.

120 Dupuis-Girod S, Buscarini E: Hereditary hemorrhagic telangiectasia: to transplant or not to transplant? Liver Int 2016;36:17411744.

121 Trembath RC: Mutations in the TGF- $\beta$ type 1 receptor, ALK1, in combined primary pulmonary hypertension and hereditary haemorrhagic telangiectasia, implies pathway specificity. J Heart Lung Transplant 2001;20: 175.

122 Abdalla SA, Gallione CJ, Barst RJ, Horn EM, Knowles JA, Marchuk DA, Letarte M, Morse $\mathrm{JH}$ : Primary pulmonary hypertension in families with hereditary haemorrhagic telangiectasia. Eur Respir J 2004;23:373-377.
123 Ayala E, Kudelko KT, Haddad F, Zamanian RT, de Jesus Perez V: The intersection of genes and environment: development of pulmonary arterial hypertension in a patient with hereditary hemorrhagic telangiectasia and stimulant exposure. Chest 2012;141: 1598-1600.

124 Shovlin CL, Gibbs JS, Jackson JE: Management of pulmonary arteriovenous malformations in pulmonary hypertensive patients: a pressure to embolise? Eur Respir Rev 2009; 18:4-6.

125 Abdulla F, Awan I, Silva B, Devlin H, Hosman A, Shovlin C: A case-control study of associations between hereditary haemorrhagic telangiectasia and common respiratory conditions. Thorax 2013;68:A194.

126 Hosman AE, Devlin HL, Silva BM, Shovlin CL: Specific cancer rates may differ in patients with hereditary haemorrhagic telangiectasia compared to controls. Orphanet J Rare Dis 2013;8:195.

127 Kjeldsen A, Aagaard KS, Tørring PM, Möller S, Green A: 20-year follow-up study of Danish HHT patients-survival and causes of death. Orphanet J Rare Dis 2016;11:157.

128 Donaldson JW, McKeever TM, Hall IP, Hubbard RB, Fogarty AW: Complications and mortality in hereditary hemorrhagic telangiectasia: a population-based study. Neurology 2015;84:1886-1893. 